WIDER Working Paper 2020/4

\title{
Social mobility in China
}

A case study of a quantitative sociological approach to social mobility research in the Global South

Yaojun $\mathrm{Li}^{*}$

January 2020 
Abstract: This study analyses intergenerational class mobility in China as a case study of a quantitative sociological approach to social mobility research in the Global South. Drawing on national representative surveys collected between 2010 and 2015 in China, the analysis focuses on absolute and relative mobility rates for men and women across four birth cohorts. With regard to absolute mobility, we find rising levels of mobility, with upward mobility prevailing over downward mobility. With regard to relative mobility, we find constancy for the older cohorts but a growing rigidity for the youngest cohort of men. The urban-rural divide is increasingly blurred, but class differences are becoming more salient, especially between the professional-managerial salariat and the rest of society in occupational and educational attainment.

Key words: social mobility, bukou, education, gender, log-linear models, symmetrical odds ratios, China

Acknowledgements: I am most grateful to the editors, Professor Paul Lambert, and the participants at the Social Mobility Workshop held on 5-6 September 2019 in Helsinki, Finland for helpful comments and suggestions. All errors in the paper are mine.

*University of Manchester, Manchester, UK, Yaojun.Li@manchester.ac.uk

This study has been prepared within the UNU-WIDER project Social mobility in the Global South-concepts, measures, and determinants.

Copyright (C) UNU-WIDER 2020

Information and requests: publications@wider.unu.edu

ISSN 1798-7237 ISBN 978-92-9256-761-3

https://doi.org/10.35188/UNU-WIDER/2020/761-3

Typescript prepared by Merl Storr.

The United Nations University World Institute for Development Economics Research provides economic analysis and policy advice with the aim of promoting sustainable and equitable development. The Institute began operations in 1985 in Helsinki, Finland, as the first research and training centre of the United Nations University. Today it is a unique blend of think tank, research institute, and UN agency — providing a range of services from policy advice to governments as well as freely available original research.

The Institute is funded through income from an endowment fund with additional contributions to its work programme from Finland, Sweden, and the United Kingdom as well as earmarked contributions for specific projects from a variety of donors.

Katajanokanlaituri 6 B, 00160 Helsinki, Finland

The views expressed in this paper are those of the author(s), and do not necessarily reflect the views of the Institute or the United Nations University, nor the programme/project donors. 
This paper investigates social mobility in developing countries. Social mobility is an indicator of economic efficiency, social justice, and political legitimacy. As such, it is an enduring concern for government decision makers, social science researchers, and wider society, in developing as well as developed countries. Yet, developing countries have lower levels of economic development and country-specific sociocultural institutions, which call for particular and more sensitive attention when we conduct mobility research. This paper gives an example of theoretically informed, methodologically rigorous, and contextually attuned mobility analysis in the Global South, using China as a case study.

China's situation is unique due to entrenched social differences exacerbated by the household registration (bukou) system. This system requires rural residents to register as agricultural bukou holders even if they are not engaged in agricultural work, as is the case for example with commune cadres, teachers, or doctors. In addition, it requires all newborn babies to register with their mother's bukou, thereby binding most Chinese people to the land at birth and for decades thereafter, with limited opportunities for upward social and geographical mobility. A direct result of this is an urban-rural divide where, under state planning, urbanites enjoy many benefits which are denied to rural residents, although there are still clear class differences among urban residents. China was also subject to Confucian indoctrination for thousands of years, whereby male preference was an open practice, causing marked gender inequality. China as we now know itthe People's Republic of China (PRC), established in 1949—-was born out of a whole series of wars against foreign invasions as well as civil wars, such that immediately after the Liberation the country was extremely poor, and it remained very poor until quite recently. However, the reform policy implemented in 1978 gradually shifted the country from one of the poorest to become the second-largest economic powerhouse in the world.

It is in this context that the analysis in this paper is situated. China's institutional, historical, and cultural barriers to mobility may or may not find similar expressions in other developing societies, as these countries may have specific urban-rural or ethno-religious differences or caste systems. While it is important to recognize country-specific differences, it is hoped that there may also be a common or similar logic when countries develop socio-economically, and that therefore, by following the logic of this paper, readers might conduct mobility research in other developing countries.

There are different approaches to conducting quantitative sociological analysis of social mobility. Owing to space limitations, we focus on intergenerational social (class) mobility in this paper.

The paper is structured as follows. In the next section, we give a brief account of the major government policies that have had and are continuing to have a large impact on social mobility. We also review existing research on intergenerational social mobility in China, conducted by Chinese and other scholars. This is followed by the presentation of data, methods, and key findings. The analysis ends with a discussion. 


\section{Social policy and mobility}

No research on class mobility in China can proceed without considering the impacts of the major government policies implemented since 1949. There are of course many policies that have impacted on people's life chances, but the most important are those related to the bukou system, the opening-up and reforms that led to the migration of over 280 million rural residents (peasants) to urban and coastal areas for jobs and a better life, and the drive to expand higher-education provision in 1999 that aimed to make the country not only an economic superpower, but also a knowledge incubator.

The bukou system was initiated in 1955 and fully implemented in 1958. Initially it was aimed at population control, as the government could not feed the growing population in the cities. After the Liberation, millions of rural people swarmed into urban centres, and the first Constitution of the PRC, promulgated in 1954, permitted free movement. Soon the government found it increasingly difficult to supply the ever-growing urban population with jobs, education, housing, transport, healthcare, pensions, and daily necessities. As a response, the government firstly called on newcomers to cities to 'voluntarily' return to their villages, and then designed a 'fundamental' solution to migration by adopting the hukou system. Over time, the system became more and more rigid, and effectively created a chasm 'between heaven and earth' (Treiman 2012), separating Chinese citizens into an 'agricultural' rural sector and a 'non-agricultural' urban sector, with rural bukou holders unable to move to cities and denied the benefits bestowed upon urbanites by the state in terms of jobs, education, housing, healthcare, pensions, and many other services. In the urban sector, the government further differentiated workplace (danwei) statuses, giving top priority to Party and government organizations, followed by state-owned enterprises, and cascading down to collective-owned enterprises (Cheng and Selden 1994, 1997). Self-employment was greatly curtailed, especially during the Cultural Revolution (1966 to 1976). Most importantly, newborn babies had (and still have) to register with their mother's bukou status. As most Chinese people were living in the countryside at that time-and more so for women than for men - this meant that the overwhelming majority of children born from the late 1950s onwards in China had rural bukou status and were destined to be peasants themselves, even if their fathers had urban bukou or worked as rural cadres, doctors, or teachers. Only 'the best and brightest' (Wu and Treiman 2007: 419) could escape this fate and become non-rural.

Hukou was therefore a paramount ascriptive factor in mobility in China. This, together with parental class, has predominantly determined the life chances of Chinese people for the last 70 years. For decades since its inception, this system has served as an effective control mechanism over the country's people, and as an especially powerful barrier for rural people. Parental positions have further strengthened the social divide. For instance, even during the most turbulent years of the Cultural Revolution, cadres' sons had a 50 per cent greater chance of receiving a senior secondary education than did peasants' sons (Deng and Treiman 1997: 421). Furthermore, around 27 million educated youths from junior and senior middle schools were sent 'up to the mountains and down to the valleys' following Chairman Mao's instructions to receive 're-education' by poor and lower-middle peasants during the same period. Even though family background had little influence on who was sent away, it had a tremendous influence on who could return earlier: those from high-ranking cadre families were over twice as likely to secure an early return to the city as their peers from ordinary working-class families (Zhou and Hou 1999: 24).

The economic reforms that started in 1978 unleashed huge creativity among the Chinese people. Factories mushroomed, making China a world factory that needed millions of workers. The rural 
reforms that started in 1978, which gradually abolished the People's Commune system, released the peasants from the land. Hundreds of millions of migrant peasant-workers surged into cities and coastal areas, seeking the dirty, dangerous, and demeaning jobs shunned by urbanites on construction sites and in restaurants, shops, and hotels, as bricklayers, waiters, cashiers, or cleaners. They were treated unequally and suffered greatly in the cities, often having to leave their children, spouses, and parents behind in the villages. Life was hard, but there was more money than if they had stayed at home as peasants. In the process, they were also upgrading the occupational structure of China, and over time many of them became skilled manual workers, lower-grade technicians, clerks, and even professionals, managers, and entrepreneurs, signifying a huge change in terms of social structure and mobility. Many migrant peasant-workers are now second generation, born and bred in cities, although they still carry the rural bukou with them and still suffer systemic discrimination. It is also noted that from the early 2000s onwards, the government launched a series of urbanization policies that aimed to turn China from a rural to an urban country, allowing rural people to register as urban residents in smaller and medium-sized cities (in big cities they still need to apply for a temporary residential permit). Many rural people are reluctant to make the change, however, and for good reasons. They do not wish to lose their homestead rights and communal benefits; furthermore, as they have remained at the bottom of Chinese society for over half a century, they also fear that they have more to lose by losing their rural bukou, and they do not have adequate socio-economic-cultural resources to compete with existing urbanites in the fierce struggle for survival in the urban labour market. These emerging features are new developments in China, but they do not pose a serious challenge to intergenerational mobility research of the kind in which we are currently engaged.

Another consideration as a driver of mobility is education. China used to be a very poorly educated country. In 1949, only 20 per cent of young people could attend primary schools. In 1998, only 9.8 per cent of the age cohort could enter higher education. In 1999, the government decided to expand the higher educational sector. Over the last 20 years, the proportion of university-educated people has increased at amazing speed. At the time of writing in 2019, there are 39 million students in China's 3,000 universities, and the gross enrolment rate for university education has exceeded 50 per cent. The quality of Chinese universities is also rising. As class destination is increasingly determined by education, the increase in higher educational provision will affect the growth of the professional-managerial salariat. But how family origins affect education, and in turn class destination, is worth serious analysis.

Finally, we must bear in mind that China is a very big country, with many differences not only between rural and urban areas, and between people in different class positions, but also between different regions and provinces. Even during the planning period, and even more so now, life in a suburban area of a big coastal city such as Beijing or Shanghai is better than life in a market town in the mountains. The impacts of regional factors and bukou origins need to be taken into account in assessing mobility patterns and trends, and this is done in the present analysis. 
To explore the patterns and trends of intergenerational social mobility in China, the present study uses pooled data from the China General Social Survey series (CGSS) for 2010, 2011, 2012, 2013, and 2015. ${ }^{1}$ The CGSS is the most widely used national representative data set in mainland China, with the widest geographical and population coverage. ${ }^{2}$

Intergenerational class mobility is chiefly concerned with movement between origins and destinations. To measure parents' and respondents' class positions, we employ a schema much used for intergenerational class mobility in China (Chen 2013; Li and Zhao 2017; Li and Zhu 2015; Li et al. 2015; Wu and Treiman 2007). Firstly, with regard to parental class, we note that an increasing proportion of Chinese mothers have higher social positions than fathers (from 3.4 to 12.6 per cent from the oldest to the youngest cohort). Although this is lower than the 20 per cent seen in Britain ( $\mathrm{Li}$ and Devine 2011), it signifies remarkable social progress. Given this, we therefore adopt the dominance approach (Erikson 1984; see also Beller 2009), using the higher parental position (whether that be the father's or the mother's position) as the class of origin.

For parents' and respondents' classes alike, we coded a five-way class schema:

1 the professional and managerial salariat (classes I and II);

2 the intermediate class of clerical, own-account, manual supervisorial, and lower technical workers (III to V);

3 skilled manual workers in commerce and industry (VI);

4 unskilled manual workers in commerce and industry (VIIa);

5 agricultural workers, also called nongmin (peasants) in Chinese terminology (VIIb).

Parental class refers to the family position when the respondent was aged 14 to 18 years, and respondent's class refers to his or her current or last main job. As the CGSS is designed for the adult population in China, we confine the analysis to those aged 18 to 65 years. Excluding cases with missing data on parents' and respondents' classes, we have an effective sample size of 38,002.

To reflect the impacts of major social policies, we use a semi-cohort approach in this analysis, with the following measurements. Cohort 1 refers to those who were born between 1945 and 1957, who received their education and entered the labour market largely before the start of the Cultural Revolution. The country was very poor at that time, with only two per cent able to receive degreelevel education. Cohort 2 refers to those who were born between 1958 and 1967 and experienced the Cultural Revolution, with a severely interrupted education: only four per cent had a degreelevel education. Cohort 3, born between 1968 and 1980, were able to enjoy the fruits of the

\footnotetext{
${ }^{1}$ Our prior analysis shows that both for the pooled sample (men and women together) and for each sex separately, there are no significant changes from one year to another in the net association between parents' and respondents' classes. However, there are significant gender differences. All details are available on request.

2 The CGSS data are available at www.cnsda.org. The CGSS is jointly conducted by the Survey Research Centre of the Hong Kong University of Science and Technology, and the Sociology Department of the People's University of China. The first survey was launched in 2003, followed annually or biannually. The 2003 survey contained only the urban sector. The survey did not cover Qinghai, Xizang, or Ningxia until 2010. The data since 2010 are therefore the most comprehensive social surveys of mainland China. The response rates are between 60 and 75 per cent, as shown in CGSS technical reports.
} 
opening-up and reform policies. In 1977, the national examination for university admissions was reinstated after a lapse of many years, allowing many of those who had lost the opportunity for higher education to have a second chance. Nearly 10 per cent of cohort 3 have a degree-level education. Finally, those born after 1981 constitute our youngest cohort, and they were the direct beneficiaries of government policies to expand the higher educational sector. In 1998, the gross enrolment rate in higher education was 9.8 per cent, with a student body of 2.06 million. Today, the rate has surpassed 50 per cent (Li 2016), with over half of young people attending higher education (C. Li 2014, 2018; Wu and Du 2018).

We conduct analyses of both absolute and relative mobility rates. The former refer to mobility between parents and children as we directly observe it, and are expressed in percentage terms; the latter refer to the results of class competition - that is, the competition to gain advantaged and avoid disadvantaged positions - and are typically expressed in terms of odds ratios. We also try to explain our findings in comparison with those found in developed countries such as Britain, where appropriate. We keep technical details to a minimum.

\section{$4 \quad$ Analysis}

\subsection{Absolute mobility}

\section{Changing class structures}

We begin by looking at the overall class distributions of parents and respondents, distinguishing between men and women as shown in Table 1. Also shown in the table are the scores on the dissimilarity index (DI) and Lieberson's (1975) net difference index (NDI). The DI indicates the percentages of cases that would have to be reallocated to make the two distributions identical, and thus is a measure of the overall difference between any two distributions. As the DI is insensitive to the ordering of the class categories and does not provide any directional statement about the differences between parents' and respondents' classes, we also use the NDI as an indication of net class decline or advancement. ${ }^{3}$

Looking at the data in Table 1, we find evidence of a major social change that occurred in China within one generation: most parents (60.4 per cent) are agricultural workers (peasants), but the proportion drops by half for sons (31 per cent) and one third for daughters ( 40.2 per cent). The proportions in professional-managerial salariat positions increase notably, from 14 to 20 and 16

\footnotetext{
${ }^{3}$ The NDI is defined as NDxy $=\operatorname{pr}(\mathrm{X}>\mathrm{Y})-\operatorname{pr}(\mathrm{Y}>\mathrm{X})$ and further defined as $\sum_{i=2}^{n} \chi_{i}\left(\sum_{j=1}^{n-i-1} \gamma_{j}\right)-\sum_{i=2}^{n} \gamma_{i}\left(\sum_{j=1}^{n-i-1} \chi_{j}\right)$ where, in our case, $\mathrm{X}$ indicates the class position of parents, and $\mathrm{Y}$ that of respondents. It is noted here that we reversed the class order in calculating the NDI, with 1 referring to peasants and 5 to the salariat. Another method to measure the association between rows and columns in a contingency table is proposed by Altham (1970; Altham and Ferrie 2007). The underlying idea of the 'Altham distance' is the mobility rates observed in one table and those deriving from a 'processed' table using an iterative adjustment procedure, as discussed in Mosteller (1968). Both Mosteller (1968) and Altham (1970) may have drawn inspiration from Deming and Staphan (1940). After some careful consideration, we decided to use Lieberson's NDI and uniform difference (UNIDIFF) models in this study rather than Altham's distance, for reasons of clearer sociological rationale, and ease of presentation and exposition.
} 
per cent for parents and male and female respondents. All of this shows increasing 'room at the top' in China, as in Britain (Goldthorpe 1987; Li and Heath 2016).

Table 1: Parents' and male and female respondents' class distribution, column percentage

\begin{tabular}{lrrr}
\hline Class & Parents & Men & Women \\
Salariat & & & \\
Intermediate & 14.0 & 20.1 & 16.3 \\
Skilled manual & 10.4 & 19.2 & 24.1 \\
Unskilled manual & 8.5 & 11.0 & 7.0 \\
Agricultural & 6.8 & 18.6 & 12.4 \\
& 60.4 & 31.1 & 40.2 \\
DI & & & \\
NDI & & 28.7 & 22.1 \\
\hline
\end{tabular}

Note: $\mathrm{N}=18,732$ and 19,270 for men and women respectively. The two indices compare men's and women's classes with those of their parents. The NDI is usually taken as ranging from -1 to 1 , but the values are here reversed and multiplied by 100 for ease of comparison with the DI. Positive values in the NDI indicate an advancement of the respondent's class relative to the father's class. All analyses here and elsewhere in this study are based on weighted data, with weights provided by the data providers.

Source: author's calculations based on data from CGSS.

Turning to the indices of dissimilarity in the lower part of the table, we see that the overall DI scores are higher for men than for women, indicating the male preference in China, where parents have tended to attach greater importance to sons' than to daughters' investment in education and career advancement. For instance, peasant families would try their best to find a non-peasant job for their sons, and working-class urban families would try to get a non-manual job for their sons. This kind of son preference disappeared for single children, but even during the years of the onechild policy (strictly enforced by law between 13 March 1982 and 1 January 2016), most rural and some urban families had more than one child. The male advantage is even more clearly shown in the NDI scores. Roughly speaking, men's chances of gaining better jobs than their parents are around 70 per cent higher relative to women's (NDI being 26.5 and 15.6 respectively).

Figure 1: Distribution of parents' and men's and women's class positions by cohort, cumulative percentage

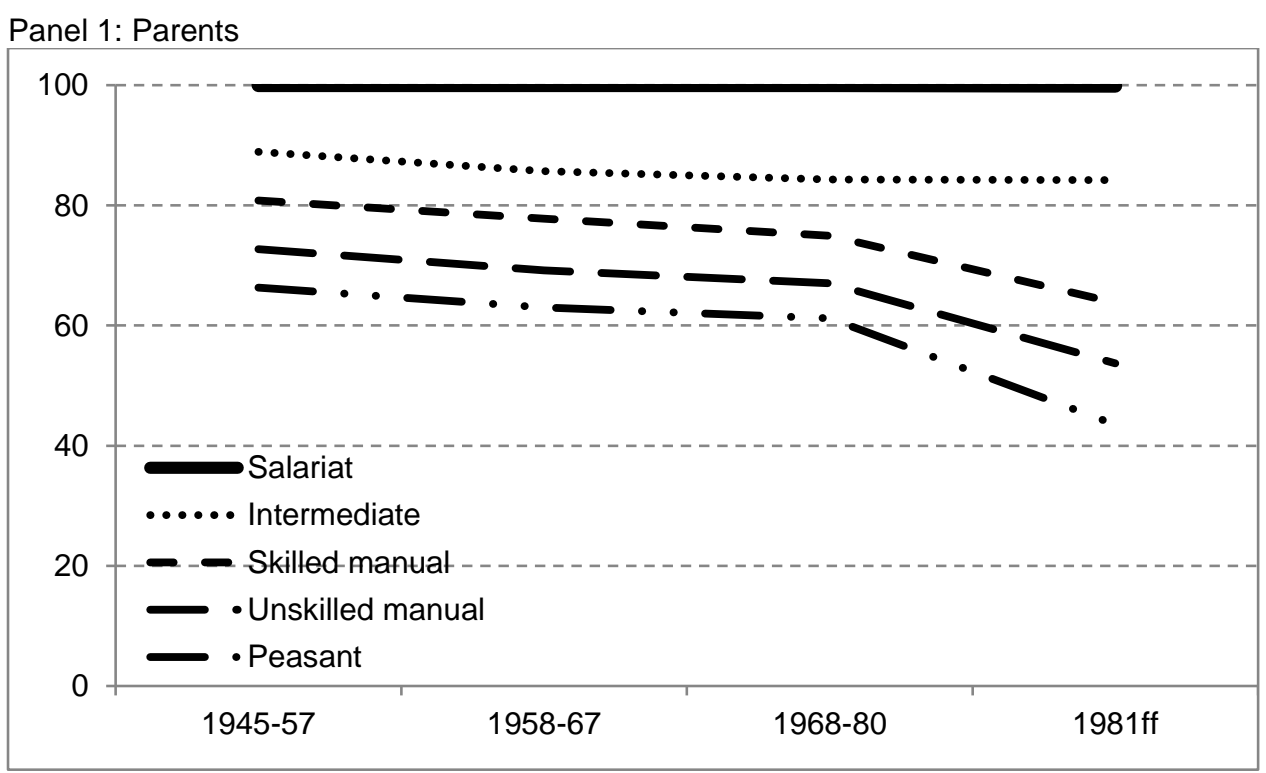



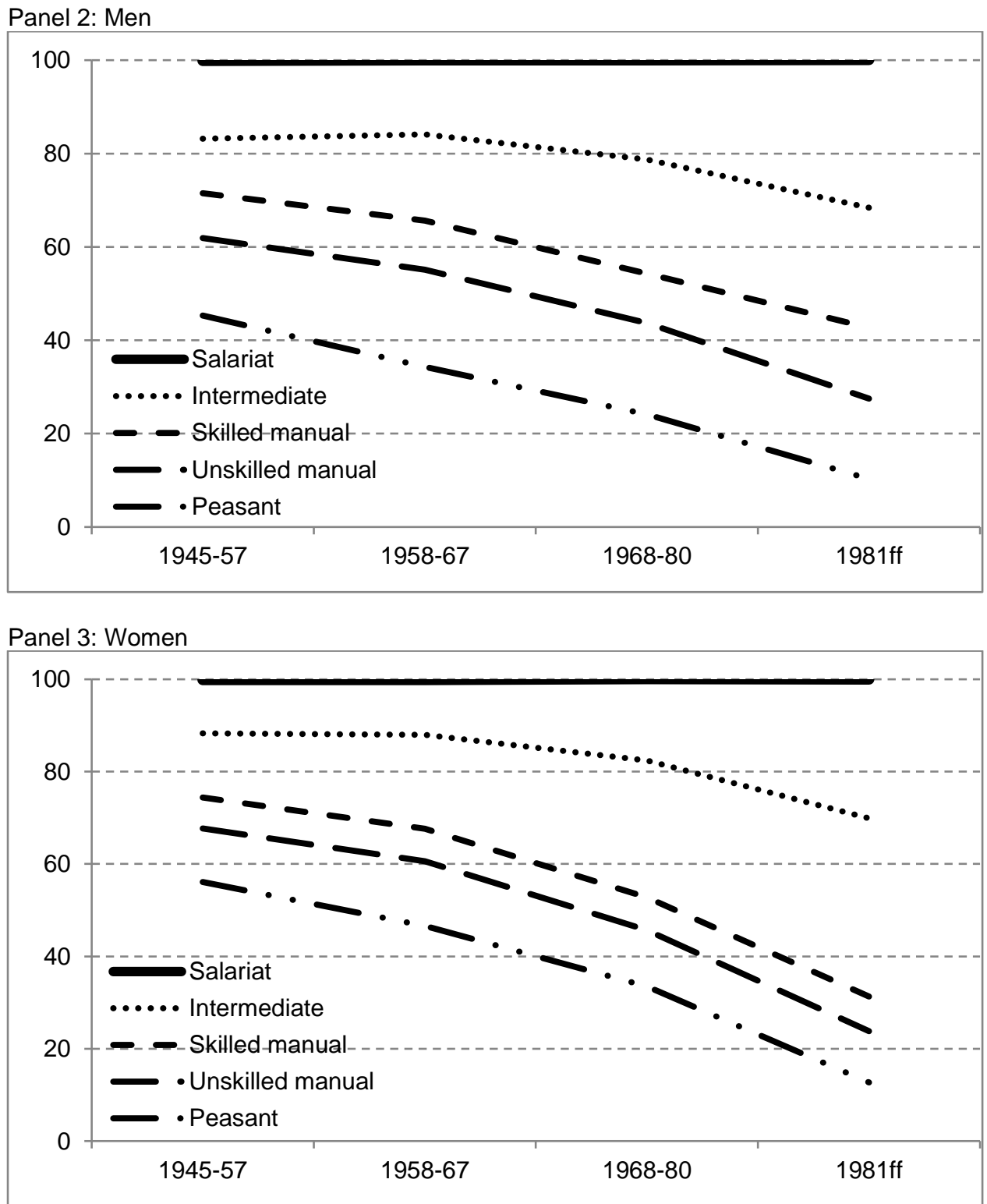

Source: author's calculations based on data from CGSS.

In order to gain a clearer view, both of the structural changes as reflected in parents' and respondents' class distributions, and of the amount of mobility and class advancement that has occurred between generations, we show the changes in occupational distribution over the four cohorts in Figure 1, and the DI and NDI data in Figure 2.

Data in Figure 1 reveal an amazing picture of occupational upgrading for a country with such a huge population and from such a low starting point. Sixty-six per cent of the parents of the oldest cohort were peasants, but the proportion drops to 44 per cent for the youngest cohort's parents. For the respondents themselves, we see that 45 per cent of the men and 56 per cent of the women in the oldest cohort are still engaged in agricultural work; but for the youngest cohort, the proportions have fallen to 10 and 13 per cent respectively. On the other hand, the proportions holding professional and managerial jobs increase from 17 to 32 per cent for male respondents, and from 12 to 30 per cent for female respondents, between the oldest and the youngest cohort. The data in Figure 2 show that although the overall DI and NDI for men are higher than for 
women, the cohort changes are actually in favour of women. For both DI and NDI, women have been making rapid progress, and in the youngest cohort are ahead of men in both sets of statistics. Women's progress is largely due to their lower starting points.

Figure 2: $\mathrm{DI}$ and NDI for men and women
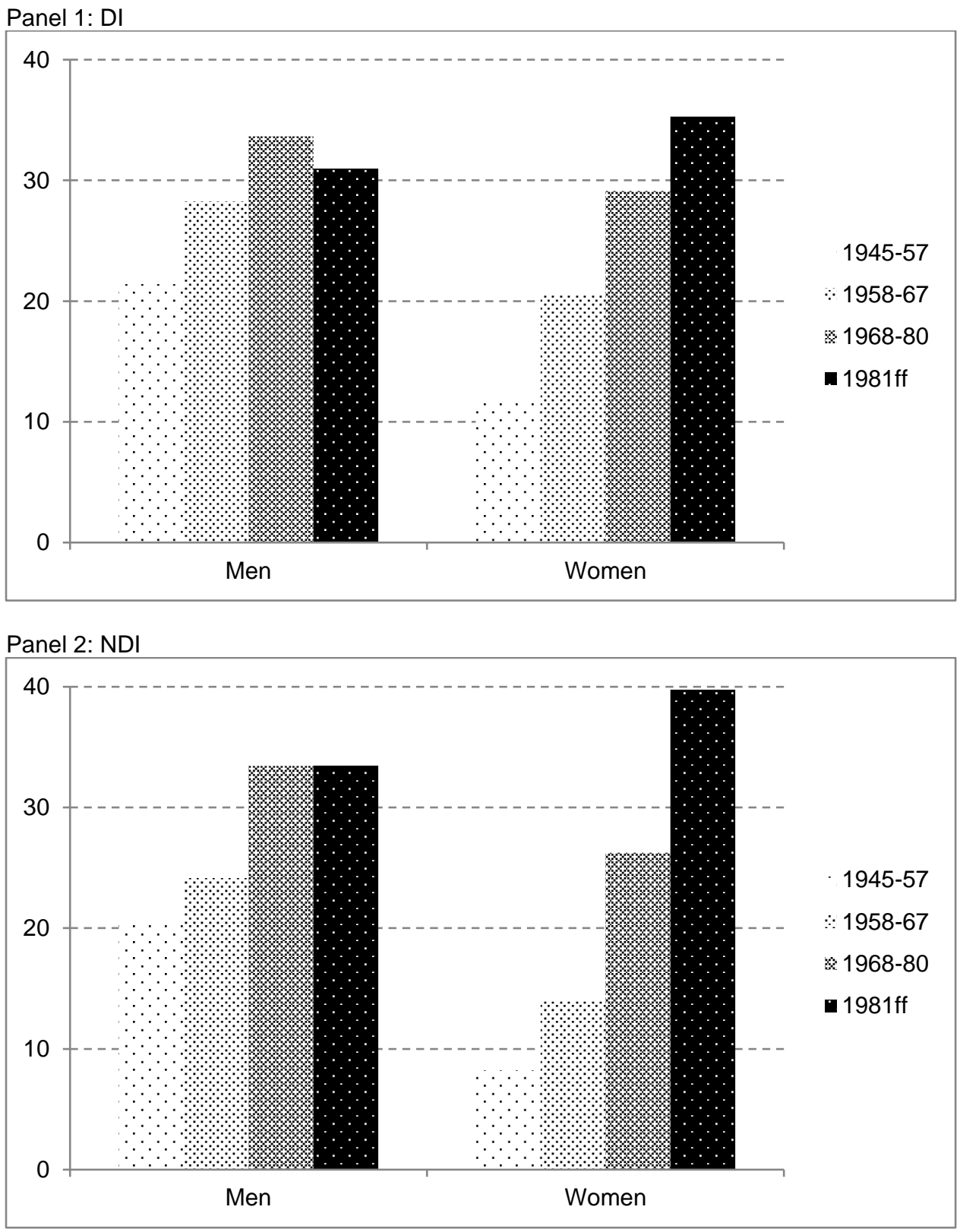

Source: author's calculations based on data from CGSS.

\section{Parent-respondent class association}

As we are concerned with social mobility, we wish to see how parents' class affects children's class. In Table 2, we show class distribution by parental class for the two gender groups. This is a table of row percentages, but it is constructed in such a way that if we had used cell percentages, then the cell values with the different colour schemes shown in the table would be easily aggregated to reveal rates of immobility and various kinds of mobility. Thus, the cells on the main diagonal (in 
black) correspond to intergenerational stability; those above the diagonal correspond to downward mobility; those below the diagonal correspond to upward mobility. Within upward and downward mobility, long-range mobility is differentiated from short-range mobility, determined by whether the movement crosses the division line of the professional-managerial salariat (Goldthorpe 1987). Movement into or out of the salariat is seen as the most decisive moment in class mobility separating long-range from short-range mobility. In our data, the rates of total, upward, downward, long-range upward, and long-range downward mobility are 56, 41, 15, 13, and four per cent respectively. In a period of rapid socio-economic change, there are more chances for upward than for downward mobility, and for long-range upward than for long-range downward mobility.

Table 2: Class distribution of respondents by class of parents (percentage by row)

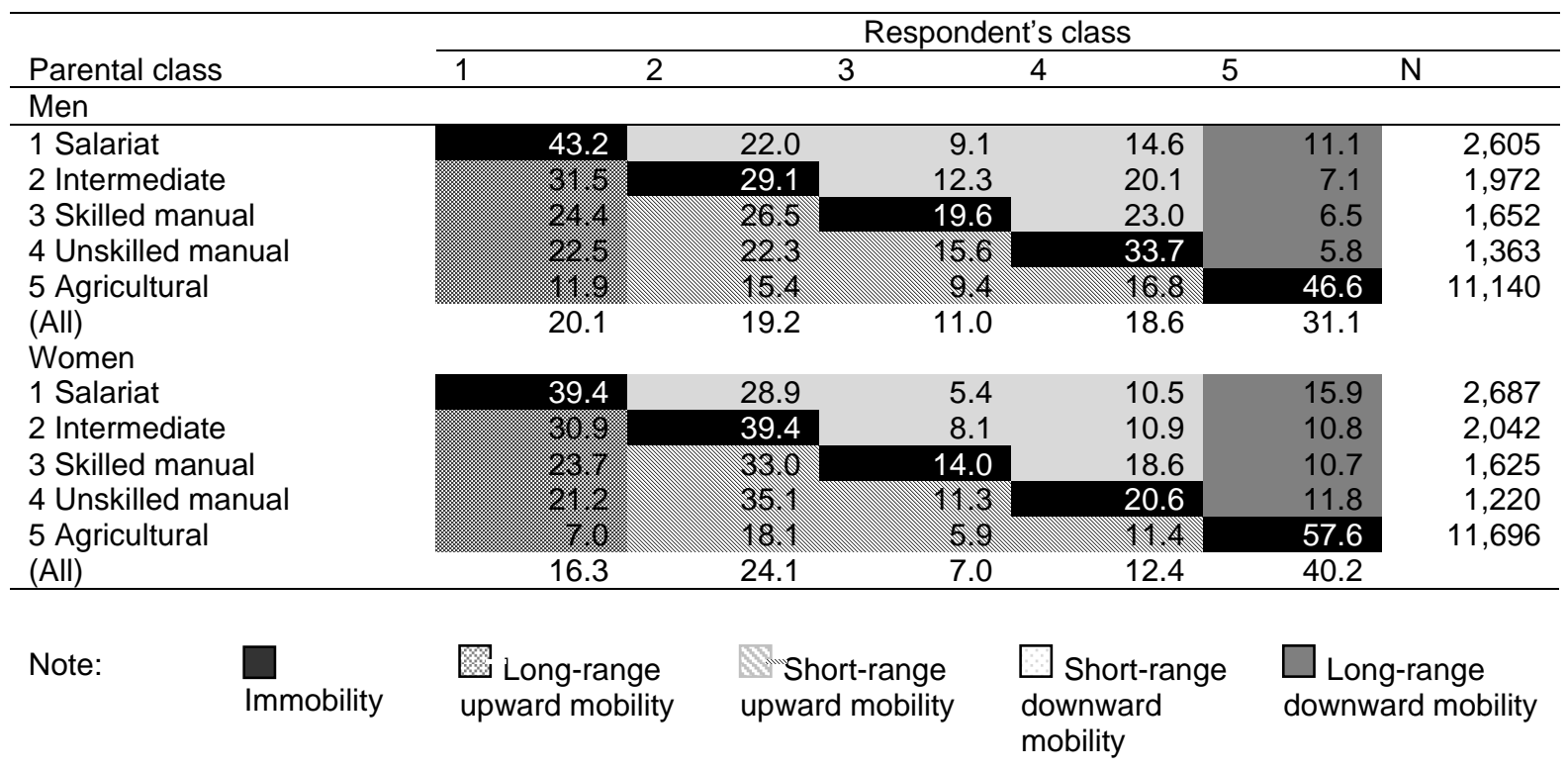

Source: author's calculations based on data from CGSS.

The data in Table 2 show three main features. The first is the clear class gradient in access to the salariat, as seen in column 1, running from 43 per cent for salariat sons to 12 per cent for peasants' sons, and from 39 per cent for salariat daughters to seven per cent for peasants' daughters. In other words, the class differences run around four to five times as high in terms of disparity ratios. Secondly, however, the opposite is not shown in the distributions to the peasant class. It is expected that peasants' sons and daughters would have a high likelihood of remaining peasants, as opportunities for upward mobility were extremely limited before the reforms. This is clearly shown in the table, with 47 per cent of sons and 58 per cent of daughters from peasant families still found as peasants. Yet, if we look at the data in column 5 of the table, we see that salariat sons and daughters are not the least likely to find themselves peasants. They are actually around four to five percentage points more likely to be peasants than those from intermediate, skilled, and unskilled manual working-class families. This kind of long-range downward mobility is rarely found in other countries and manifests itself as a Chinese characteristic, reflecting China's sociopolitical system. As parental class is measured by the job of the higher-class parent, and as fathers usually have higher-class jobs than mothers, it means that children whose mother was a peasant but whose father was a cadre or professional will have a rural bukou, just like those from families where both parents were peasants. Children with rural bukou status, regardless of their father's class, are expected to remain peasants, and further analysis indeed shows that 96 per cent of those experiencing long-range downward mobility have a rural bukou. At that time, and to some extent 
even today, the rural-urban divide was a chasm 'between heaven and earth' (Treiman 2012). Our findings in this respect corroborate Wu and Treiman (2007) in showing that long-range downward mobility was far from trivial in socialist China; moreover, since their analysis was limited to men, we can go further in showing that the situation is even more serious for women. Thirdly, the table reveals marked social inequalities in China. If we just focus on the top and bottom, we can see that the chances of people from salariat families finding themselves in salariat positions and avoiding peasant positions is 15.2 and 20.4 times greater for men and women respectively than those from peasant families facing the same competition. This social inequality is even greater than that found in Britain by Bukodi and Goldthorpe (2019: 81).

Figure 3: Total, upward, downward, long-range upward, and long-range downward mobility by cohort and sex Panel 1: Men
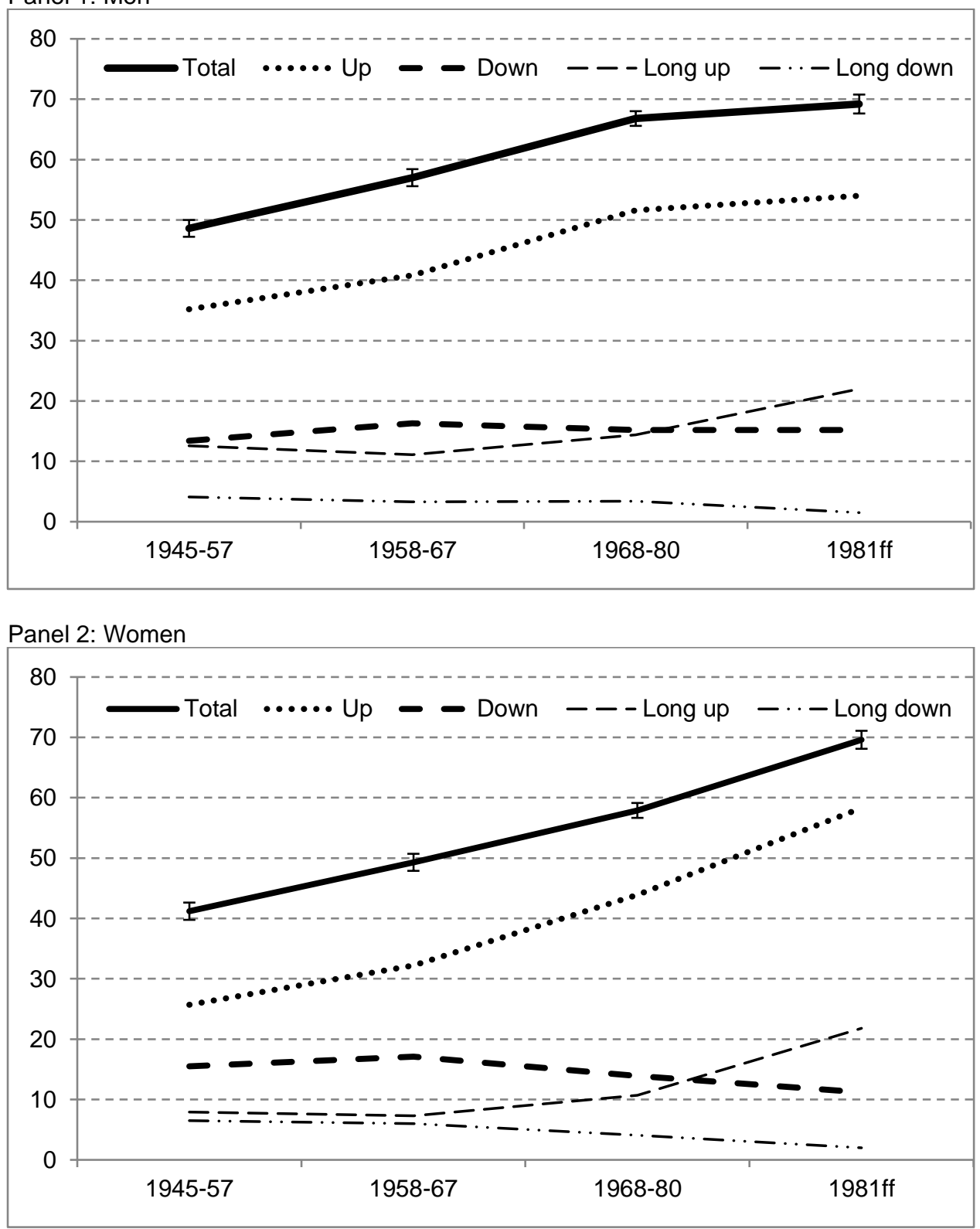

Source: author's calculations based on data from CGSS. 
As a way of investigating social change in intergenerational class mobility, Figure 3 shows rates of total, upward, and downward mobility across the cohorts. Immobility is simply the proportion found along the diagonal of the mobility table. Within upward and downward mobility, we further differentiate long-range upward and downward mobility, as discussed above. We show the various rates for men and women separately. For total mobility, we also show the 95 per cent confidence intervals.

For both men and women, we see clear evidence of a continuing increase in mobility rates, from 49 to 69 per cent from the oldest to the youngest cohort for men, and 41 to 69 per cent for women. Total mobility is composed of upward and downward components, and here we find, again for men and women alike, that the former is steadily on the rise, while the latter is on quite a flat line. If we look more closely, we find that long-range upward mobility rates actually exceed downward rates for the youngest cohort for both men and women. Long-range downward mobility, on the other hand, is at a very low level, and there are signs of decline.

The evidence presented above on absolute mobility rates suggests a positive note on the changing social structure, with growing room at the top, more equal gender relations, and greater opportunities for upward than downward mobility, although grave class disparity is also found with particular respect to access to the salariat. Our next question is: have rising opportunities created a more equal society in China? It is to this question that we turn our attention in the following.

\subsection{Relative mobility}

Turning to relative mobility, our research questions focus on whether or not the association between class origins and destinations is becoming more fluid at the overall level, and in which specific areas class competition is becoming more or less strenuous. In other words, is there greater equality of opportunity across the cohorts? Are women catching up with men?

Relative mobility refers to the competition between people from different classes of origin to gain access to advantaged positions and avoid disadvantaged positions, and is expressed in odds ratios. The closer the odds ratio is to one (or $\log$ odds to zero), the weaker the origin-destination association, and the greater the social equality. The further an odds ratio rises above one, the stronger the association between origin and destination, and the more unequal the mobility chances. Conversely, the further an odds ratio falls below one, the more equal the mobility chances.

\section{Overall trends of inequality}

To address questions on relative mobility at the overall level, we use log-linear and uniform difference (UNIDIFF) models, and we fit three models. The first is the conditional independence model, which proposes that all odds ratios defining origins and destinations are at a value of one. The second is the constant social fluidity model (CnSF), which allows for an association between origins and destinations but not for three-way interactions: in other words, this model postulates that the association between origin and destination remains constant across the cohorts. The third is the UNIDIFF model, which provides an assessment of the direction and magnitude of changes in the association between origin and destination across the cohorts, ${ }^{4}$ testing whether there is a

4 The models can be written as follows. Baseline model (conditional independence): $\log \mathrm{Fijk}=\mu+\lambda \mathrm{iO}+\lambda \mathrm{jD}+\lambda \mathrm{kY}$ $+\lambda \mathrm{ikOY}+\lambda \mathrm{jkDY}$. CnSF model: $\log F \mathrm{jjk}=\mu+\lambda \mathrm{iO}+\lambda \mathrm{jD}+\lambda \mathrm{kY}+\lambda \mathrm{ikOY}+\lambda \mathrm{jkDY}+\lambda \mathrm{ijOD}$. Log multiplicative or 
uniform pattern for the odds ratios to be closer to (or further away from) one in a particular layer of the table. We run the models separately for men and women.

Table 3 shows the results of fitting the log-linear and UNIDIFF models to the mobility tables for men and women across the cohorts. For both men and women, we find that none of the three models provide an adequate fit to the data. Even though the UNIDIFF models give a statistically significant improvement in fit over the CnSF models for both men and women, the Bayesian information criterion (BIC) statistics still favour the CnSF models.

Table 3: Results of fitting the conditional independence, CnSF, and UNIDIFF models to mobility tables for men and women, by birth cohort

\begin{tabular}{lrrrrrr}
\hline Model & $\mathrm{G}^{2}$ & $\mathrm{df}$ & $\mathrm{p}$ & $\mathrm{RG}^{2}$ & $\mathrm{BIC}$ & $\triangle$ \\
Men & & & & & & \\
1. Cond. ind. & 4227.6 & 64 & 0.00 & 0.0 & 3595.4 & 18.6 \\
2. CnSF & 197.8 & 48 & 0.00 & 95.3 & -276.3 & 3.2 \\
3. UNIDIFF & 179.4 & 45 & 0.00 & 95.8 & -265.1 & 2.9 \\
2. - 3. & 18.4 & 3 & 0.00 & & & \\
Women & & & & & & \\
4. Cond. ind. & 4835.9 & 64 & 0.00 & 0.0 & 4207.5 & 21.2 \\
5. CnSF & 129.4 & 48 & 0.00 & 97.3 & -341.9 & 2.5 \\
6. UNIDIFF & 119.6 & 45 & 0.00 & 97.5 & -322.3 & 2.4 \\
5. -6. & 8.8 & 3 & 0.03 & & & \\
& & & & & &
\end{tabular}

Notes: $N=19,511$ and 18,387 for men and women respectively. $R G^{2}$ : percentage reduction in $G^{2} . \triangle$ : percentage of cases misclassified.

Source: author's calculations based on data from CGSS.

In Figure 4, we show the $\beta$ parameter estimates returned from the UNIDIFF models for men and women, together with the 95 per cent confidence intervals, with the oldest cohort as the reference point. The data do not fully support the idea of trendless fluctuation. For men, the first three cohorts show little change, but the youngest cohort is clearly different, indicating a significant rise of inequality. For women, the second and third cohorts indicate signs of growing equality, but the youngest cohort returns to the level of the oldest cohort. Overall, the data show rising inequality for men but a trendless fluctuation for women.

UNIDIFF model: $\log F i j k=\mu+\lambda i O+\lambda j D+\lambda k Y+\lambda i k O Y+\lambda j k D Y+\beta k X i j .0$ stands for class origin, $D$ for class destination, and $\mathrm{Y}$ for cohort; Xij represents the general pattern of the origin-destination association, and $\beta \mathrm{k}$ the relative strength of this association. 
Figure 4: UNIDIFF parameter estimates and 95 per cent confidence intervals across birth cohorts

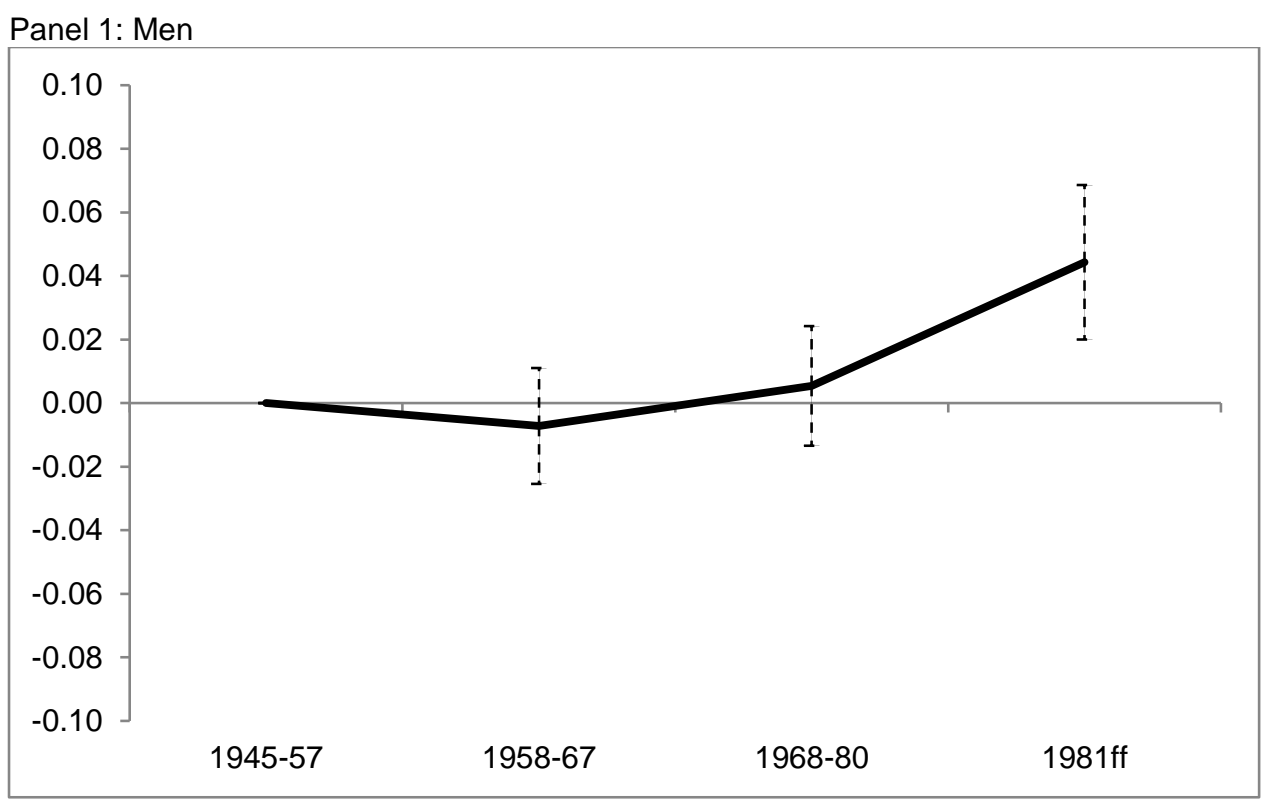

Panel 2: Women

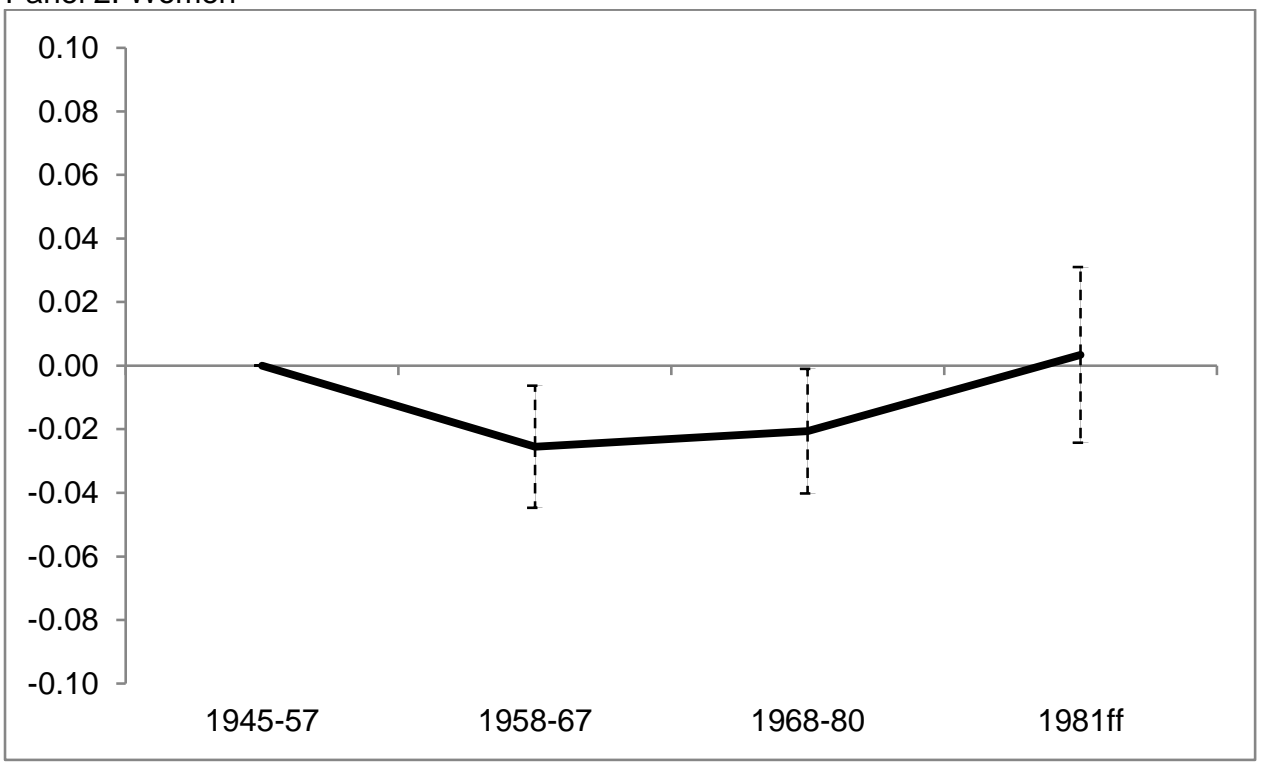

Source: author's calculations based on data from CGSS.

\section{Locus of class competition}

The findings in Figure 4 prompt us to make further queries. Do all kinds of class competition become fiercer from older to younger cohorts of men? Do all such competitions remain at a similar level of strength for women? Questions like these cannot be addressed using log-linear and UNIDIFF models, which, while good at capturing patterns of social fluidity at the global level, are not good at identifying specific features of social inequality at the local level (Goldthorpe and Jackson 2007). To explore the questions more closely, we calculate symmetrical odds ratios involving the same pairs of origin and destination classes in the same kinds of competition to gain access to certain (advantaged) and avoid certain other (disadvantaged) class positions. We do this 
for men and women separately, and for each cohort. In calculating the odds ratios, we also take into account the effects of year of survey. ${ }^{5}$

Table 4 shows the data for symmetrical odds ratios, with each row representing a cohort (C1 to C4). With the exception of a small number of odds ratios shown in italics, all other odds ratios are statistically significant at the 0.05 level or above, but such significance is not otherwise indicated. The data with asterisks show significant differences with the odds ratios for cohort 1 in a particular kind of class competition.

Take the data for men. The cell value for the first row (the oldest cohort, C1) in column 5 is 11.28 , indicating that compared with peasants' sons, sons from cadre and professional (salariat) families are around 11 times as likely to have a salariat rather than a peasant job. This shows marked social inequality. When we move down from the oldest to the youngest cohort (from C1 to C4), we find that the odds ratios stay at similar levels for the next two cohorts (14.84 and 13.22), but for the youngest cohort it rises sharply to 34.63, representing a highly significant change from the oldest cohort. These odds ratios suggest that social inequality for men is already marked for the older cohorts but becomes twice as severe for the youngest cohort, adding more evidence to the data for men in Figure 4. To the best of our knowledge, the severity of social inequality shown here is only matched by that found in early 1970s Britain for men in the competition between the higher salariat and unskilled manual workers (Goldthorpe 1987: 112).

Yet, not all class competitions become more severe for men. Only class competitions involving classes 1:5 and 2:5 become notably greater from the older to the youngest cohorts, whereas those for classes 3:5 and 4:5 experience a sharp decline, plummeting from around 23 to 25 for the two oldest cohorts to around five to six for the youngest cohorts, both representing highly significant changes; the magnitude of reduction is even higher for the competition between classes 4:5. What explains this is that in the past, working-class jobs were preserved for people with urban bukou and were inaccessible to peasants, rendering a huge advantage to urbanites, even those from workingclass families. However, in the last few decades, access to manual working-class positions has no longer been a privilege, and peasant-workers (as they are called in China) have become the mainstay of China's 'working class' (P. Li 2018). The same picture is shown for the two younger cohorts for women. For both men and women, we see a blurring worker-peasant division, which in China's specific context marks clear social change and social progress. The manual working class and peasants are coming closer to each other, becoming more equal, or being similarly disadvantaged.

\footnotetext{
${ }^{5}$ A technical complication in using the cohort approach for conducting symmetrical odds ratios pertains to the variable dating of the destination position of respondents in the same cohort, rendering it difficult to estimate the populationlevel fluidity at a particular date (Goldthorpe and Mills 2004). Yet, if one's interest is not in the fluidity at any particular date, the cohort approach, as Breen et al. (2009) observe, will have advantages: people in the same cohort will have been sampled at different time points, and assuming the use of systematic surveying methods and no major population-level disruptions (conditions fully met by the data used in this study), then pooling the surveys together and designing appropriate cohorts will produce more reliable results than using a single data set. Furthermore, the five surveys were collected very close to one another, making 'variable dating' a non-significant issue (see footnote 1). To be on the safe side, we take the survey effects into account where appropriate by controlling for year of survey in some of the modelling exercises.
} 
Table 4: Symmetrical odds ratios for the four cohorts

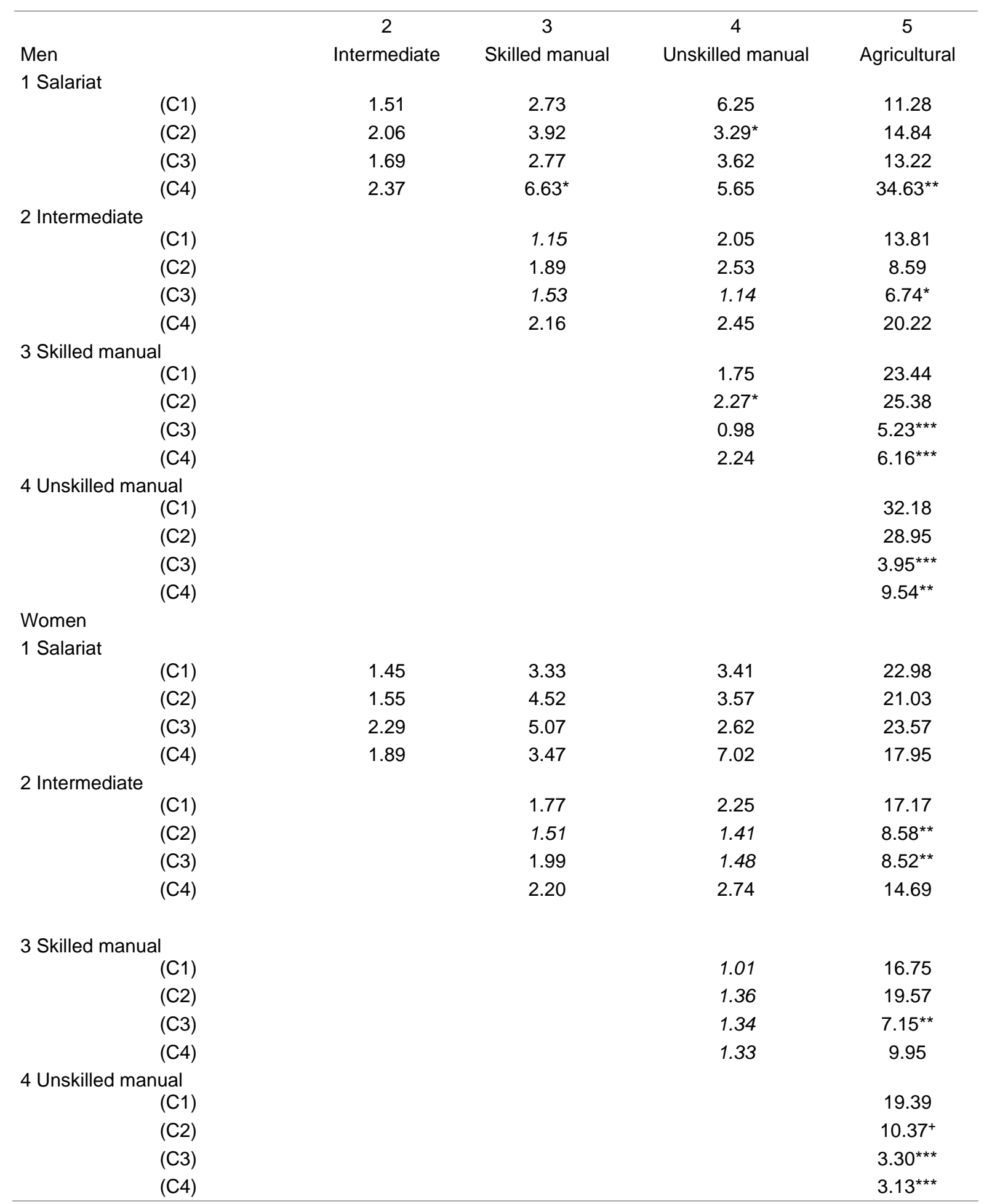

Note: the rows in each set refer to the four cohorts $(\mathrm{C} 1-\mathrm{C} 4)$ respectively. All odds ratios are calculated controlling for year of survey, and those in italics are not significant at the 0.05 level. Significance tests are conducted for cohort differences in the odds ratios, with cohort 1 as reference: ${ }^{+}<0.10 ;{ }^{*} p<0.05 ;{ }^{* *} p<0.01 ;{ }^{* * *} p<0.001$.

Source: author's calculations based on data from CGSS. 


\section{Further interrogation of processes of class mobility}

We noted above that China's socio-economic situation is highly complicated and requires a consideration not only of parents' and respondents' class, gender, and cohort, but also of bukou origins and uneven regional development. The relative mobility rates discussed above in terms of log-linear, UNIDIFF, and symmetrical odds ratios did not allow us to dwell deeply on such complications. We now proceed to such an analysis.

The categories we have constructed for parents' and respondents' classes run from the professional-managerial salariat to peasants, which constitutes a fairly clear order in China's situation. Given this, we can conduct an ordered logit analysis taking into account survey year, bukou origin, and region as covariates, following Breen et al. (2009) and Li and Heath (2016). Again, we do this separately for men and women, and for each of the four cohorts. We use parental salariat as the reference category, so that we can see how people from each of the other classes fare in the competition with their salariat peers to access more advantaged and avoid more disadvantaged positions.

Figure 5 shows the changing relationships between classes, controlling for the effects of bukou origin, regional differences, and time of survey. For both men and women, the social distances between the salariat and other classes increases, especially notably for men in the youngest cohort.

While the picture presented in Figure 5 shows an overall contour of changing class relations in accessing more advantaged and avoiding more disadvantaged social positions across the cohorts, the shifting attractions of skilled and unskilled manual positions vis-à-vis peasant positions (revealed in Table 4) would require additional assessments which would go beyond the space limitations of this paper. Sociologically, differentiating between the relative importance of manual working-class positions and peasant positions is also less substantively important than differentiating between the salariat and others. Given this, we focus on access to the salariat, again controlling for the covariates as in Figure 5.

In Figure 6, we show results of logistic regression models on access to the salariat, with coefficients translated into percentage terms for ease of exposition. For both men and women, we see that origin class differences increase in the competition for privileged salariat positions from the oldest to the youngest cohort. Indeed, the class differentiation proceeds at a more rapid pace than that found in the overall competition for more advantaged positions shown in Figure 5. The gap between peasants' and salariat sons in attaining salariat positions is 19.6 percentage points for the oldest cohort, and becomes 28.4 points for the youngest cohort; the corresponding figures are 15.8 and 32 percentage points for women. In other words, gaining access to the salariat rather than to intermediate or working-class positions is assuming a more important role for the Chinese people. 
Figure 5: Ordinal logit models by cohort and gender: class origin effects across cohorts, controlling for survey effects, hukou origin, and region
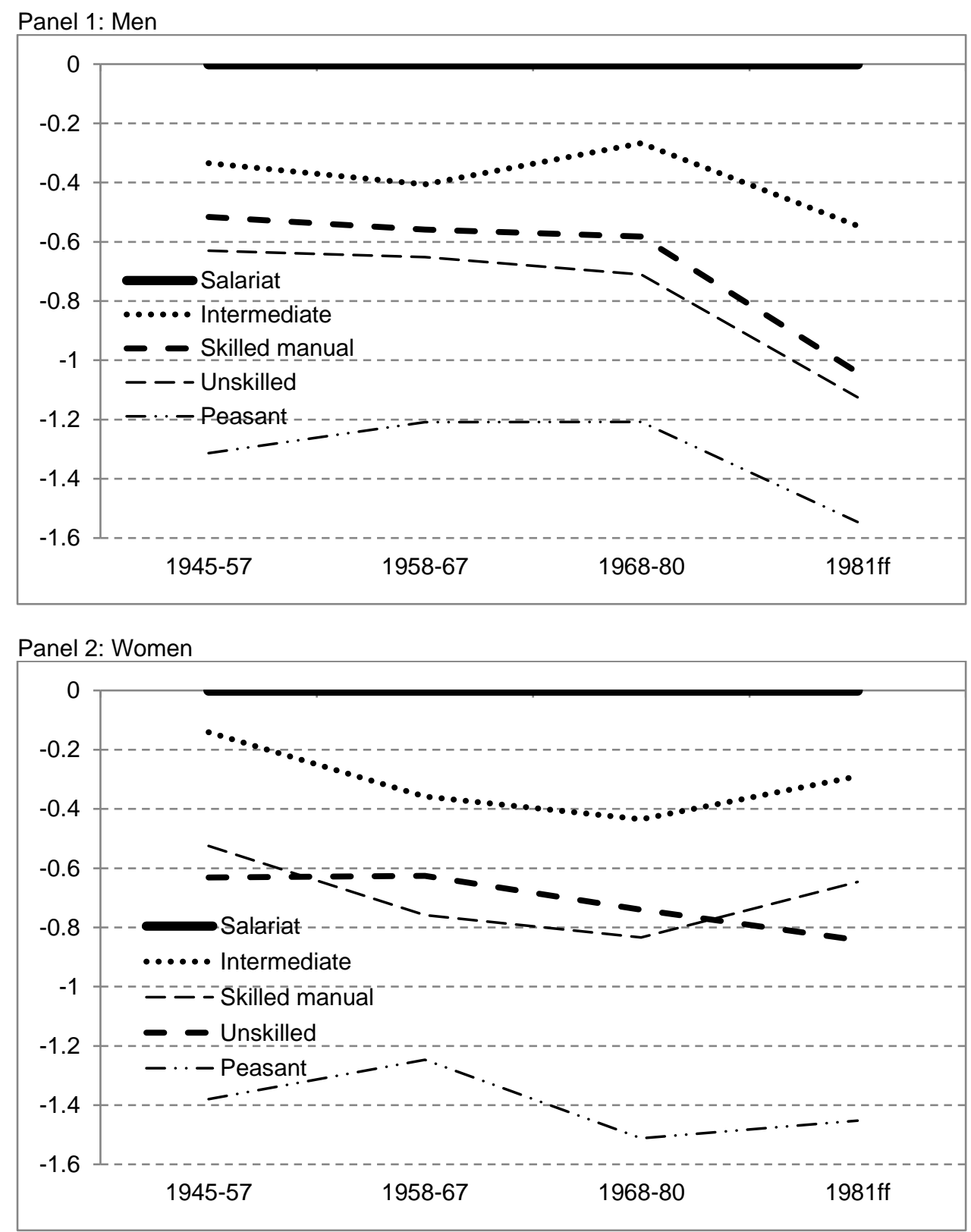

Source: author's calculations based on data from CGSS. 
Figure 6: Average marginal effects on access to the salariat, by parental class, cohort, and gender, controlling for survey effects, hukou origin, and region
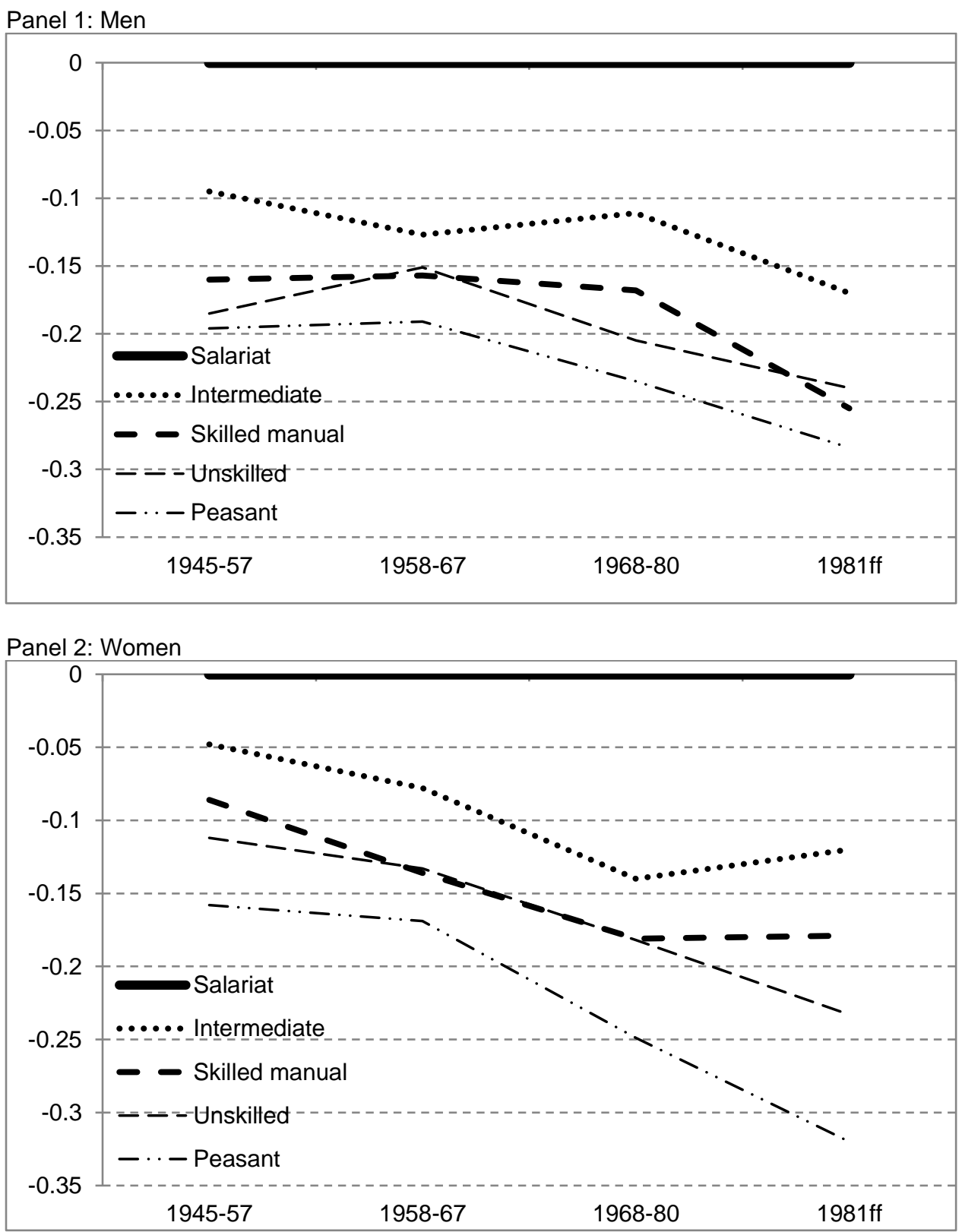

Source: author's calculations based on data from CGSS.

Why, then, did the social distances become larger when the national economy was developing rapidly? Many studies have shown that while the gross domestic product was high in China, economic polarization was also taking shape, and the more privileged would make use of the resources at their disposal to help secure more favourable positions for their children in educational and career development. We can see the class differences in degree-level education in Figure 7. Here we find that the gap between salariat children and peasants' children in gaining a degree-level education consistently increases, moving from seven to 10, 20, and 30 percentage points for men, and from four to eight, 21, and 43 points for women, from the oldest to the youngest cohort. This gives ample evidence for the maximum maintained inequality thesis by Raftery and Hout (1993) and the effectively maintained inequality thesis by Lucas (2001), although 
we are not focusing on access to elite universities. ${ }^{6}$ The clear class divergences in university education show that a rising tide does not lift all boats equally. Greater opportunities only serve to exacerbate existing class differences (see also Li and Bian 2020, forthcoming).

Figure 7: Access to degree-level education by parental class, sex, and cohort
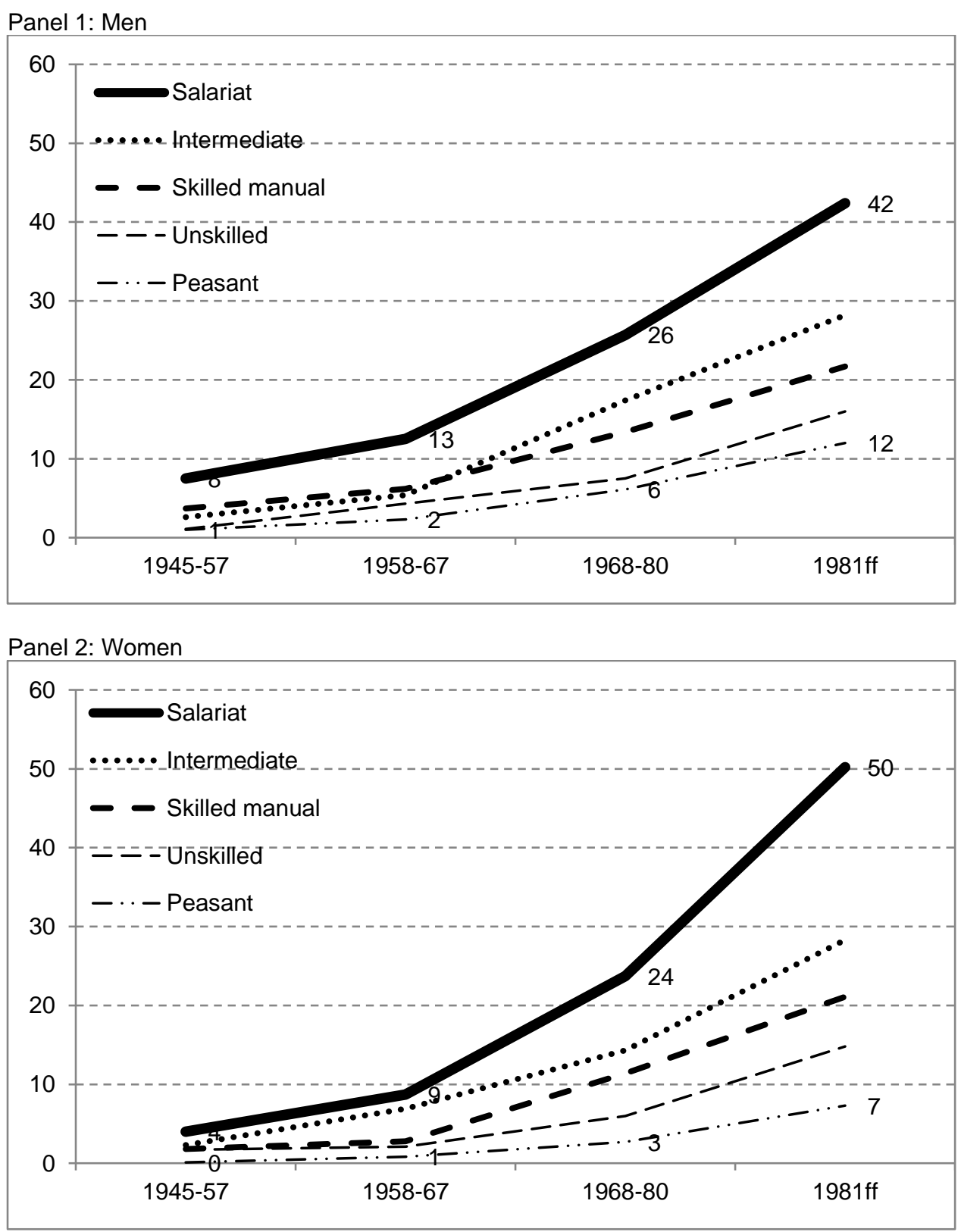

Source: author's calculations based on data from CGSS.

\footnotetext{
${ }^{6}$ China currently has three systems for classifying elite universities: 'double-first' institutions, namely, first-class disciplines in first-class universities; ' 985 ' universities, which include the 39 most prestigious universities; and the 121 universities in the '211' group, which includes the 985 universities. There are around 3,000 universities in China, with 40 million university students, and a gross enrolment rate of 50 per cent as of 2019. For a study of class differences in attendances at the key middle schools, see Wu (2013).
} 


\section{$5 \quad$ Discussion and conclusion}

In this section, we first give a brief summary of the main findings on intergenerational social mobility in China, and then move on to offer some reflections on how the Chinese case might shed some light on mobility research in the Global South.

With regard firstly to the analysis in this study, we used the data from the five most recent years of the CGSS (2010 to 2015), as they have the greatest geographical coverage of the 31 provinces and municipalities in mainland China. We designed the class schema to reflect China's sociopolitical institutional configurations. The construction of the class schema and birth cohorts to reflect the social changes in China during the last few decades was a delicate issue, but hopefully our analysis has shown that they served their purposes quite well. The main findings are:

- A considerable occupational upgrading has taken place during the last few decades, with the proportion involved in agricultural work declining from around 50 per cent in the oldest cohort to around 10 per cent in the youngest cohort. The proportion engaged in professional and managerial work has doubled from around 15 to 31 per cent. A similar upgrading also has also taken place for parental class, although to a lesser extent.

- The upgrading has entailed much intergenerational class mobility and advancement, especially for women, with upward mobility rates much higher than downward mobility rates. Even the long-range upward mobility rates are at a similar level to, or a higher level than, downward mobility rates.

- However, social equality, as measured by relative mobility, was found to be declining. Further analysis showed that in the competition to access the most advantaged salariat and avoid the most disadvantaged peasant positions, men in the youngest cohort show a greater difference than those in the older cohorts. It was also found that advantages associated with skilled/unskilled positions vis-à-vis peasant positions have declined rapidly among the younger cohorts, for men and women alike, reflecting the gradual loosening of bukou control, industrialization, and the need for manual workers, who are largely recruited from the constant influx of migrant peasant-workers.

- We therefore found a picture of rising opportunity coupled with rising inequality. Take degree-level education as an example. As there are more opportunities for higher education, people of all class backgrounds have increased their take-up. But while peasants' sons have increased by 11 percentage points from the oldest to the youngest cohort, salariat sons have increased by 34 points. The class differentials are even bigger for women, with an increase of seven points for peasants' daughters but 46 points for salariat daughters. All classes have benefited, but those in privileged positions have benefited much more.

Our main finding of rising opportunity plus rising inequality gives substantive evidence for popular and media observations about the rigidification of the social structure in China, but it is at odds with mainstream findings on social mobility in Western (including former socialist) countries. Goldthorpe (1987), Erikson and Goldthorpe (1992), Goldthorpe and Mills (2004, 2008), Goldthorpe and Jackson (2007), and Bukodi and Goldthorpe (2019) are the best exemplars of the thesis of 'constant association' in class mobility, a thesis explained in terms of rational action theory (Goldthorpe 2007) or loss aversion theory (Kahneman 2011). Breen et al. $(2009,2010)$ and Li and Heath (2016) show signs of optimism in terms of educational and class attainment, that is, a somewhat weakening association between origin and destination. This, they hold, is due to the 
state provision of schooling, state help in higher education, and the adoption of the welfare state in developed countries since World War II, which has reduced the difference in living conditions between the middle and working classes, or to the influx of immigrants into Western countries, which may have created a somewhat greater social fluidity in the mobility structure. Findings of increasing inequality are not common. For the developing countries, Torche (2005) shows a picture of inequality mixed with fluidity.

The endogenous mobility regimes theory (see Featherman et al. 1975; Jones 1992) underlying the constancy thesis is based on the existence of the nuclear family, a market economy, and liberal democracy. China does not seem to meet all the criteria here, but our findings could be explained by the privileged making better use of their socio-economic-cultural resources to consolidate their family positions, first in education, and then in the labour market. As the economy rapidly develops, socio-economic disparity also increases.

As the countries in the Global South are so different from one another, China's mobility experience may not fit all other countries, but the underlying idea of class competition may run along similar lines.

\section{References}

Altham, P.M. (1970). 'The Measurement of Association of Rows and Columns for an R X S Contingency Table'. Journal of the Royal Statistical Society, 32(1): 63-73.

Altham, P.M., and J.P. Ferrie (2007). 'Comparing Contingency Tables Tools for Analyzing Data from Two Groups Cross-Classified by Two Characteristics'. Historical Methods, 40(1): 3-16.

Beller, E. (2009) 'Bringing Intergenerational Social Mobility Research into the Twenty-first Century: Why Mothers Matter'. American Sociological Review, 74: 507-28.

Breen R., R. Luijkx, W. Müller, and R. Pollak (2009). 'Nonpersistent Inequality in Educational Attainment: Evidence from Eight European Countries'. American Journal of Sociology, 114: 1475-521.

Breen R., R. Luijkx, W. Müller, and R. Pollak (2010). 'Long-Term Trends in Educational Inequality in Europe: Class Inequalities and Gender Differences’. European Sociological Review, 26(1): 3148.

Bukodi, E., and J.H. Goldthorpe (2019). Social Mobility and Education in Britain: Research, Politics and Policy. Cambridge: Cambridge University Press.

Chen, M. (2013). 'Intergenerational Mobility in Contemporary China'. Chinese Sociological Review, 45(4): 29-53.

Cheng, T., and M. Selden (1994). 'The Origins and Social Consequences of China's Hukou System'. China Quarterly, 139: 644-68.

Cheng, T., and M. Selden (1997). 'The Construction of Spatial Hierarchies: China's Hukou and Danwei Systems'. In T. Cheek and T. Saich (eds), New Perspectives on State Socialism of China. Armonk: Sharpe.

Deming, W., and F. Stephan (1940). 'On a Least Squares Adjustment of a Sampled Frequency Table When the Expected Marginal Totals Are Known'. Annals of Mathematical Statistics, 11: 427-44. 
Deng, Z., and D.J. Treiman (1997). 'The Impact of the Cultural Revolution on Trends in Educational Attainment in the People's Republic of China'. American Journal of Sociology, 103: 391-428.

Erikson, R. (1984). 'Social Class of Men, Women and Families'. Sociology, 18: 500-14.

Erikson, R., and J.H. Goldthorpe (1992). The Constant Flux. Oxford: Clarendon Press.

Featherman, D., F. Jones, and R. Hauser (1975) 'Assumptions of Mobility Research in the US: The Case of Occupational Status'. Social Science Research, 4: 329-60.

Goldthorpe, J.H. (1987). Social Mobility and Class Structure in Modern Britain. Oxford: Clarendon Press.

Goldthorpe, J. (2007). On Sociology. Stanford: Stanford University Press.

Goldthorpe, J.H., and M. Jackson (2007). 'Intergenerational Class Mobility in Contemporary Britain: Political Concerns and Empirical Findings'. British Journal of Sociology, 58(4): 526-46.

Goldthorpe, J.H., and C. Mills (2004). 'Trends in Intergenerational Class Mobility in Britain in the Late Twentieth Century'. In R. Breen (ed.), Social Mobility in Europe. Oxford: Oxford University Press.

Goldthorpe, J.H., and C. Mills (2008). 'Trends in Intergenerational Class Mobility in Modern Britain: Evidence from National Surveys'. National Institute Economic Review, 205: 83-100.

Jones, F. (1992). 'Common Social Fluidity: A Comment on Some Recent Criticism'. European Sociological Review, 8: 233-37.

Kahneman, D. (2011). Think Fast and Slow. London: Allen Lane.

Li, C. (2014). 'The Changing Trend of Educational Inequality in China (1940-2010): Re-examining the Urban-Rural Gap in Educational Opportunity' (in Chinese). Sociological Research, 2: 65-89.

Li, C. (2018). 'The Role of Education in Social Stratification' (in Chinese). In P. Li (ed.), Changes in Social Stratification and Class Division in Contemporary China (in Chinese). Beijing: Social Sciences Academic Press.

Li, L., and B. Zhu (2015). 'Changing Patterns of Intergenerational Mobility in Contemporary China' (in Chinese). Chinese Social Sciences, 5: 40-58.

Li, P. (2018). 'Social Stratification and Class Structure in China: Changes, Issues and Policy Responses' (in Chinese). In P. Li (ed.), Changes in Social Stratification and Class Division in Contemporary China (in Chinese). Beijing: Social Sciences Academic Press.

Li, W. (2016). 'The Gross Admission Rate Will Surpass 50\% in China's Institutes of Higher Education' (in Chinese). Evening Newspaper of Law and Order, 7 April, 2016. Available at: news.ifeng.com/a/20160407/48383154_0.shtml (accessed 21 January 2020).

Li, Y., and Y. Bian (eds) (2020, forthcoming). Social Inequalities in China. London: World Scientific and Imperial College Press.

Li, Y., and F. Devine (2011). 'Is Social Mobility Really Declining? Intergenerational Class Mobility in Britain in the 1990s and the 2000s'. Sociological Research Online, 16(3): 4. Available at: www.socresonline.org.uk/16/3/4.html (accessed 9 January 2020).

Li, Y., and A. Heath (2016). 'Class Matters: A Study of Minority and Majority Social Mobility in Britain, 1982-2011’. American Journal of Sociology, 122(1): 162-200. 
Li, Y., S. Zhang, and J. Kong (2015). 'Social Mobility in China and Britain: A Comparative Study'. International Review of Social Research, 5(1): 20-34.

Li, Y., and Y. Zhao (2017). 'Double Disadvantages: A Study of Ethnic and Hukou Effects on Class Mobility in China (1996-2014)'. Social Inclusion, 5(1): 5-19.

Lieberson, S. (1975). 'Rank-Sum Comparisons Between Groups'. In D. Heise (ed.), Sociological Methodology. San Francisco: Jossey-Bass.

Lucas, S. (2001). 'Effectively Maintained Inequality: Education Transitions, Track Mobility, and Social Background Effects'. American Journal of Sociology, 106: 1642-90.

Mosteller, F. (1968). 'Association and Estimation in Contingency Tables'. Journal of the American Statistical Association, 63: 1-28.

Raftery, A., and M. Hout (1993). 'Maximally Maintained Inequality: Expansion, Reform, and Opportunity in Irish Education: 1921-75'. Sociology of Education, 66(1): 41-62.

Torche, F. (2005). 'Unequal but Fluid: Social Mobility in Chile in Comparative Perspective'. American Sociological Review, 70: 422-50.

Treiman, D.J. (2012). 'The "Difference Between Heaven and Earth": Urban-Rural Disparities in Well-being in China'. Research in Social Stratification and Mobility, 30: 33-47.

Wu, X., and D.J. Treiman (2007). 'Inequality and Equality Under Chinese Socialism: The Hukou System and Intergenerational Occupational Mobility'. American Journal of Sociology, 113(2): 41545.

Wu, Y. (2013). 'The Keypoint School System, Tracking and Educational Stratification in China, 1978-2008' [in Chinese]. Sociological Research, 4: 179-202.

Wu, Y., and S. Du (2018). 'The Development of Higher Education Over 40 Years Since China's Reform and Opening-up' (in Chinese). Journal of Social Development, 2: 1-21.

Zhou, X., and L. Hou (1999). 'Children of the Cultural Revolution: The State and the Life Course in the People's Republic of China'. American Sociological Review, 64(1): 12-36. 